\title{
НАНО- И СУБМИКРОННЫЕ ЧАСТИЦЫ НА ОСНОВЕ САМООРГАНИЗУЮЩИХСЯ СОПОЛИМЕРОВ В КАЧЕСТВЕ СИСТЕМ ДОСТАВКИ ЦИТОСТАТИКОВ
}

\author{
А.Ю. Джужа², Н.Н. Зашихина', М.Л. Левит', И.И. Тарасенко', \\ Е.Г. Коржикова-Влах \\ ${ }^{1}$ Институт химии, Санкт-Петербургский государственный университет, \\ 198504, Россия, Санкт-Петербург, Университетский пр., 26. \\ ${ }^{2}$ Институт высокомолекулярных соединений, Российская академия наук, \\ 199004, Россия, Санкт-Петербург, Большой пр., 31.
}

DOI: 10.19163/MedChemRussia2021-2021-206

E-mail:vlakh@hq.macro.ru

Разработка новых систем доставки лекарств является одним из лидирующих направлений в области создания безопасных и эффективных цитостатических лекарственных препаратов. Среди существующего многообразия нано- и микрочастиц, рассматриваемых для доставки цитостатиков, полимерные нано- и микрочастицы имеют ряд преимуществ, таких как широкая вариация состава и структуры сополимеров, более высокая емкость загрузки лекарственного вещества (ЛВ), возможность пролонгированного высвобождения ЛВ, вариация функциональных групп на поверхности, возможность модификации поверхности частиц векторами для адресной доставки, и т.д.

В рамках данной работы получена серия амфифильных сополимеров различного состава и строения, небиодеградируемых и обладающих способностью к биодеградации, на основе которых за счет самоорганизации в водных средах были получены нано- и субмикронные наночастицы различной морфологии. Характеристики последних были установлены с использованием различных физико-химических методов, а именно, динамического и электрофоретического рассеяния света, анализа траектории наночастиц, просвечивающей электронной микроскопии. Все полученные системы были протестированы на предмет цитотоксичности, клеточного проникновения и скорости захвата макрофагами.

Наиболее перспективные полимерные системы были выбраны для инкапсулирования гидрофобных и амфифильных цитостатических субстанций. С использованием нескольких раковых клеточных линий проведено изучение и сравнение цитотоксичности полученных инкапсулированных форм со свободными ЛВ в растворе. Установлено, что инкапсулированные цитостатики сохраняли биологическую активность в отношении раковых клеток на уровне свободных лекарственных субстанций или превосходили последние, в то время как сами системы доставки не демонстрировали цитотоксических эффектов. Таким образом, некоторые из разработанных систем имеют перспективы дальнейшей апробации в экспериментах in vivo.

Работа выполнена при поддержке Российского научного фонда (проект №21-73-20104)

и с использованием оборудования Научного парка СПбГУ.

$$
-206-
$$

